\title{
PERBAIKAN SISTEM PRODUKSI KARDUS DENGAN PENDEKATAN LEAN DMAI DI PT KEDAWUNG CCB
}

\author{
Achmad Amiruddin Santoso ${ }^{1}$, Ahmad Fatih Fudhla ${ }^{2}$ \\ e-mail : achmadamirudin425@gmail.com,fatih_fudhla@dosen.umaha.ac.id \\ Fakultas Teknik, Jurusan Teknik Industri, Universitas Maarif Hasyim Latif \\ Jl. Ngelom Megare, Taman Sidoarjo 61257
}

\begin{abstract}
ABSTRAK
Kapasitas produksi di PT. Kedawung Setia CCB masih belum sesuai target akibat adanya kegagalan produksi. Oleh karena itu, dalam penelitian ini digunakan pendekatan lean DMAI untuk dapat memenuhi target yang diharapkan. Tahapan metode ini dimulai dengan mengidentifikasi waste yang paling berpengaruh diantara 4 waste yang ada. Kemudian membuat dekripsi sistem dan pareto chart dilanjutkan dengan analisa, RCA dan FMEA untuk mengetahui akar penyebab masalah dan nilai tertinggi RPN. Dari hasil pengolahan data diperoleh, defect sebagai waste yang paling berpengaruh. Nilai Risk Priority Number (RPN) tertinggi sebesar 126 terdapat pada jenis defect berupa karton rusak akibat dari penataan sheet yang kurang maksimal dan mesin yang sering rusak. Oleh karena itu, pada tahap improve perlu dilakukan pemeliharaan mesin. Dari hasil penelitian diperoleh waktu rata-rata pemeliharaan korektif (MCT) pada mesin printing adalah 1,2 jam dan waktu pemeliharaan preventive adalah 1 jam. Waktu rata-rata diantara kerusakan atau MTBF ialah 142,85 jam yang berarti mesin akan mengalami kerusakan setelah rata-rata beroperasi selama 142,85 jam atau 5,9 hari dan nilai ini juga menunjukkan umur operasi mesin.
\end{abstract}

Kata kunci: kardus, lean DMAIC, pemeliharaan mesin, waste.

\section{PENDAHULUAN}

Persaingan dalam dunia industri yang semakin ketat, memacu perusahaan manufacturing untuk meningkatkan daya saingnya. Dengan cara peningkatan mutu produk, konsistensi ketersediaan, rantai pasok produk hingga jasa layanan pelanggan, serta harga (Pane, 2017). Untuk mencapai itu semua maka salah satu usaha yang dapat dilakukan adalah dengan mengurangi pemborosan dalam berbagai hal termasuk penyediaan bahan baku, lalu lintas bahan, pergerakan operator, pergerakan alat dan mesin, waktu tunggu proses, kerja ulang dan perbaikan.

PT. Kedawung Setia CCB (KSCCB) merupakan perusahaan yang bergerak di bidang industri pembuatan kardus, produksi dilakukan berdasarkan permintaan yang masuk (Make to Order). Dari hasil wawancara diperoleh kapasitas real di perusahaan sebesar 70.000 sheet dalam satu shift sedangkan perusahaan mentargetkan 75.000 sheet dalam satu shift. Selisih yang terjadi cukup besar dari target yang di harapkan dalam satu shift.

Selisih target yang cukup besar diharapkan dapat diminimalisir dengan mengurangi jumlah waste melalui metode lean DMAIC. Dengan jumlah waste yang berkurang pemborosan dari biaya dapat dihindari. Lebih tepatnya bisa menekan biaya produksi serta bisa meminimalisir pengerjaan ulang (rework).

\section{METODE PENELITIAN}

Penelitian ini berkaitan dengan perbaikan sistem produksi melalui minimalisasi waste. Untuk itu, penerapan metode lean DMAI dilakukan agar dapat mencapai target produksi yang di harapkan. Konsep DMAIC dikenal dengan siklus define, measure, analyze, improve dan control (Pande, S. Peter; P. Neuman, Robert; R. Cavanagh, 2006). Berikut ini adalah langkah-langkah yang dilakukan

1. Studi lapangan dan studi literatur untuk mengidentifikasi masalah dan mendapatkan referensi penelitian.

2. Pengumpulan data dengan wawancara dan observasi.

3. Pada tahap define dilakukan pendeskripsian pada proses produksi dan mesin produksi (big picture mapping).

4. Pada tahap measure dilakukan identifikasi waste pada sistem produksi.

5. Pada tahap analyze dilakukan analisa dari waste yang menggunakan metode root cause analysis (RCA) dan failure mode effects analysis (FMEA).

6. Pada tahap improve dilakukan perbaikan pada waste yang paling utama.

7. Pada tahap control dilakukan pengontrolan hasil improvement. Namun pada penelitian ini tahap kontrol tidak dilakukan karena terkendala waktu penelitian. 


\section{HASIL DAN PEMBAHASAN}

Tahapan pertama dari siklus DMAIC adalah define. Pada tahap ini diperoleh big picture mapping aliran informasi proses produksi dan aliran fisik proses produksi. Aliran informasi PT. KSCCB dimulai dari supplier sampai ke customer seperti yang ditunjukkan pada gambar 1 dibawah ini.
Sedangkan aliran fisik dimulai dari proses kedatangan bahan baku dari supplier yang digunakan untuk pembuatan karton. Adapun bahan baku pembuatan karton antara lain kertas roll, tepung tapioka , air , batubara dan sebagainya. Bahan baku ini yang ada di gudang bahan baku lalu disiapkan untuk dibawa ke area Corrugating. Gambar aliran fisik proses produksi karton dapat dilihat pada gambar 2.

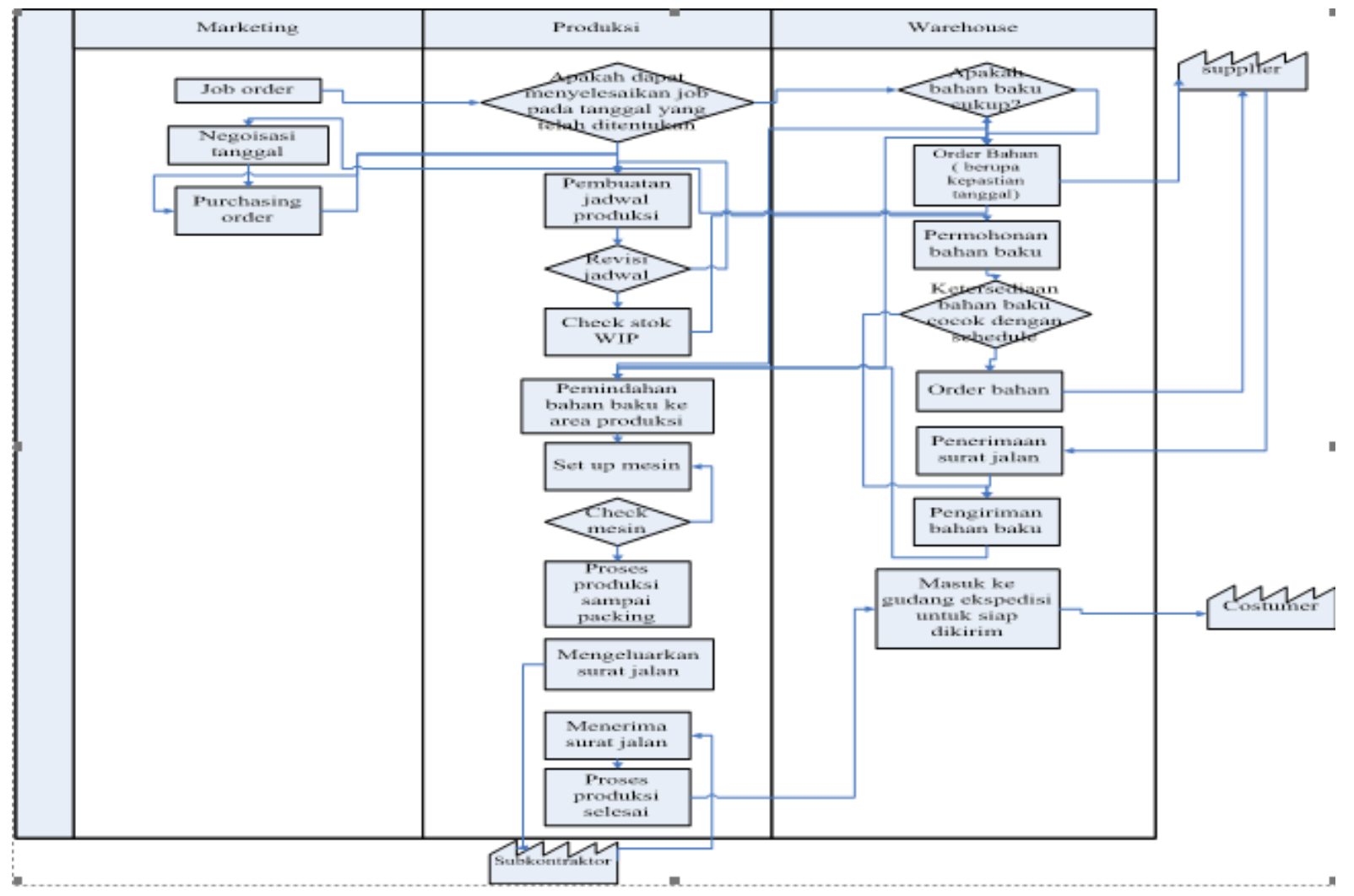

Gambar 1. Aliran informasi proses produksi karton

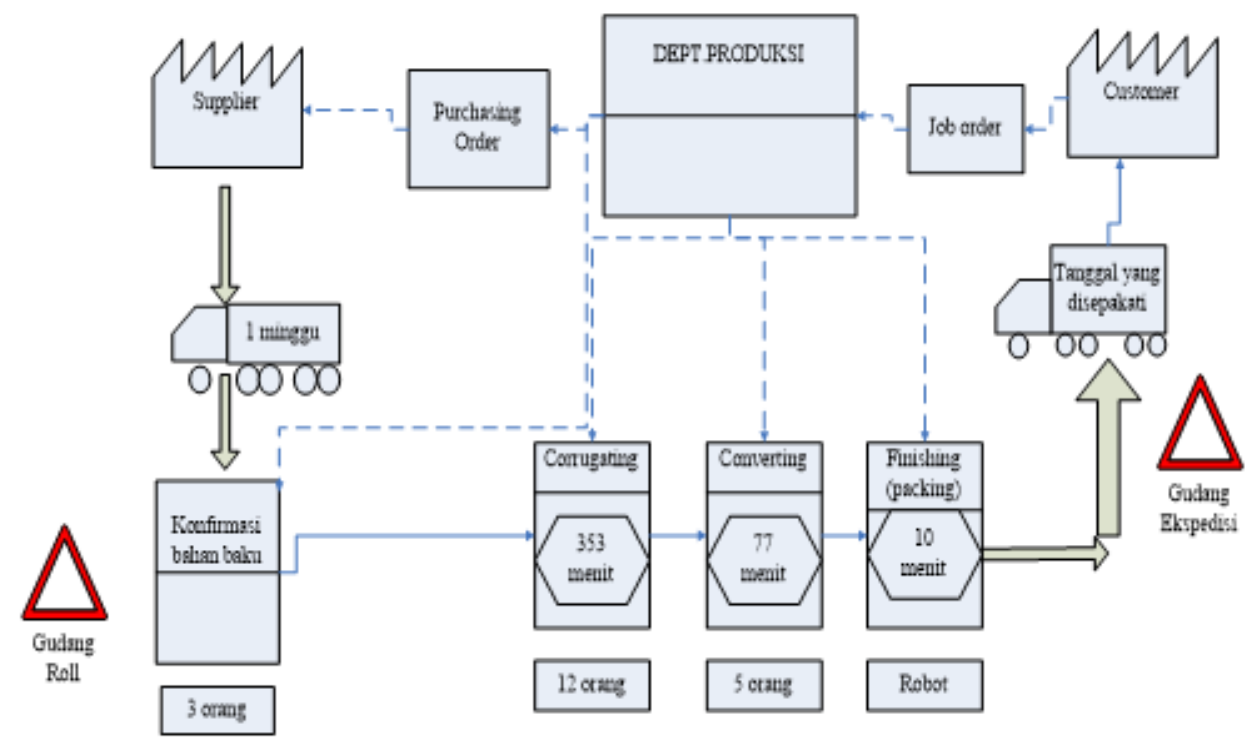

Gambar 2. Aliran fisik proses produksi karton 
Pada tahap measure dilakukan identifikasi waste yang terjadi pada proses produksi.. Dari gambar aliran proses produksi di atas area yang paling sering terjadi waste berlebihan ialah area converting mesin flexo inline. Ada 4 waste yang muncul di mesin tersebut yaitu Environmental, Health, and Safety, Defect, Overproduction, dan Waiting. Berikut penjelasannya :

1. Environmental, Health, and Safety

Yaitu waste kecelakaan kerja yang terjadi di mesin flexo 7, 8, 10, dan 11 seperti yang ditunjukkan pada tabel 1 dibawah ini.

Tabel 1. Jumlah kecelakaan kerja periode bulan JanuariJuni 2017

\begin{tabular}{|c|c|c|c|}
\hline No & Jenis Kecelakaan & $\begin{array}{l}\text { Jumlah } \\
\text { Karyawan } \\
\text { (orang) }\end{array}$ & $\begin{array}{l}\text { Jumlah } \\
\text { frekuensi } \\
\text { (kali) }\end{array}$ \\
\hline 1 & $\begin{array}{l}\text { Jari tangan putus } \\
\text { terkena belting } \\
\text { mesin }\end{array}$ & 3 & 2 \\
\hline 2 & $\begin{array}{l}\text { Jari tangan } \\
\text { terjepit silinder } \\
\text { mesin }\end{array}$ & 2 & 3 \\
\hline 3 & $\begin{array}{l}\text { Tangan sobek } \\
\text { terkena sheet }\end{array}$ & 2 & 20 \\
\hline 4 & $\begin{array}{l}\text { Kaki terkena baut } \\
\text { conveyor }\end{array}$ & 3 & 10 \\
\hline 5 & $\begin{array}{l}\text { Tangan putus } \\
\text { terjepit gear } \\
\text { mesin }\end{array}$ & 1 & 4 \\
\hline 6 & Kaki tergelincir & 1 & 5 \\
\hline 7 & $\begin{array}{l}\text { Kaki bengkak } \\
\text { terkena conveyor }\end{array}$ & 2 & 10 \\
\hline \multicolumn{2}{|c|}{$\begin{array}{c}\text { Total jumlah kecelakaan } \\
\text { kerja dan Total } \\
\text { frekuensi }\end{array}$} & 14 & 54 \\
\hline
\end{tabular}

\section{Defect}

Yaitu waste kerusakan produk yang terjadi di mesin flexo 7, 8, 10,dan 11. Jenis - jenis kerusakan produk pada bulan Januari - Juni 2017 antara lain :

a. Printing tidak rata (melobor) yaitu cacat yang disebabkan oleh pompa tinta terlalu cepat sehingga pada saat printing sheet tinta melobor dengan total cacat sebesar 22325 produk.

b. Join gap tidak standar yaitu cacat yang memiliki ciri- ciri jarak antar flap box terlalu rapat ataupun lebar melebihi standar perusahaan yaitu $2 \mathrm{~mm}$ dengan total cacat sebesar 8640 produk.

c. Slotter tidak sesuai standar yaitu cacat yang di sebabkan oleh pisau slotter yang tidak sesuai ukuran dengan total cacat sebesar 7809 produk.

d. Karton rusak (gembos, krepek,dll) yaitu cacat yang disebabkan oleh mesin corrugating pada saat proses penggabungan kertas campurannya kurang misalnya kurang pemberian tepung tapioka dan air dengan total cacat sebesar 5700 produk.

e. Karton pecah luar atau dalam yaitu cacat yang disebabkan oleh kurangnya tekanan dan pemberian air pada saat printing sheet atau sheet terlalu keras dengan total cacat sebesar 4509 produk.

\section{Overproduction}

Yaitu waste yang terjadi karena kelebihan jumlah produksi. Pada penyajian tabel 2 dapat dilihat jumlah kelebihan produksi mesin flexo 7, 8, 10, dan 11 selama bulan Januari - Juni 2017.

Tabel 2.Jumlah kelebihan produksi periode bulan Januari - Juni 2017

\begin{tabular}{|c|c|c|c|}
\hline Bulan & $\begin{array}{c}\text { Jumlah yang } \\
\text { diproduksi } \\
\text { (lembar) }\end{array}$ & $\begin{array}{l}\text { Jumlah } \\
\text { kelebihan } \\
\text { produksi } \\
\text { (lembar) }\end{array}$ & $\begin{array}{l}\text { Jumlah } \\
\text { frekuensi } \\
\text { (kali) }\end{array}$ \\
\hline Jan-17 & 15055049 & 27084 & 6702 \\
\hline Feb-17 & 17143400 & 28000 & 8500 \\
\hline Mar-17 & 14824400 & 17300 & 4900 \\
\hline Apr-17 & 15197450 & 13050 & 3700 \\
\hline Mei-17 & 15455035 & 22885 & 5870 \\
\hline Jun-17 & 17915975 & 34225 & 9900 \\
\hline \multicolumn{2}{|c|}{$\begin{array}{l}\text { Total kelebihan dan } \\
\text { Total frekuensi }\end{array}$} & 142544 & 39572 \\
\hline
\end{tabular}

\section{Waiting}

Yaitu waste yang disebabkan oleh waktu tunggu yang berlebihan. Adapun rincian waktu tunggu bisa dilihat pada tabel 3 .

Tabel 3. Jumlah waktu tunggu periode bulan Januari - Juni Mesin flexo7, 8, 10, dan 11

\begin{tabular}{|c|c|c|c|}
\hline No & $\begin{array}{l}\text { Jenis waktu } \\
\text { tunggu }\end{array}$ & $\begin{array}{l}\text { Jumlah waktu } \\
\text { tunggu (menit) }\end{array}$ & $\begin{array}{c}\text { Jumlah } \\
\text { Frekuensi } \\
\text { (kali/menit) }\end{array}$ \\
\hline 1 & Stel order & 63495 & 11500 \\
\hline 2 & Ngelap & 20000 & 11450 \\
\hline 3 & $\begin{array}{l}\text { Service } \\
\text { mesin }\end{array}$ & 3640 & 1660 \\
\hline 4 & Order kosong & 1560 & 1360 \\
\hline 5 & $\begin{array}{c}\text { Tunggu } \\
\text { campur tinta }\end{array}$ & 5070 & 3155 \\
\hline 6 & $\begin{array}{l}\text { Tunggu } \\
\text { bahan }\end{array}$ & 4415 & 2150 \\
\hline 7 & $\begin{array}{c}\text { Pencarian } \\
\text { bahan }\end{array}$ & 7628 & 3450 \\
\hline 8 & $\begin{array}{l}\text { Perbaikan } \\
\text { mesin tali }\end{array}$ & 5222 & 3200 \\
\hline 9 & $\begin{array}{l}\text { Masalah } \\
\text { pisau }\end{array}$ & 4210 & 1895 \\
\hline 10 & Lain-lain & 4817 & 2344 \\
\hline \multicolumn{2}{|c|}{$\begin{array}{l}\text { Total waktu tunggu } \\
\text { dan Total frekuensi }\end{array}$} & 120057 & 42164 \\
\hline
\end{tabular}

Dari keempat waste diatas, kemudian diidentifikasi waste mana yang paling berpengaruh. menggunakan diagram pareto seperti yang ditunjukkan 
pada gambar 3. Dari gambar tersebut dapat diketahui bahwa waste yang paling berpengaruh ialah defect sebesar 71,97\%, selanjutnya waiting $14,44 \%$, overproduction $13,55 \%$, environmental health, and safety $0,018 \%$. Sehingga perbaikan dapat dilakukan di waste defect pada 3 jenis cacat tertinggi yaitu join gap tidak standar, karton rusak (gembos, krepek,dl), dan slotter melebihi standar.

Jumlah frekuensi wasteyang paling berpengaruh

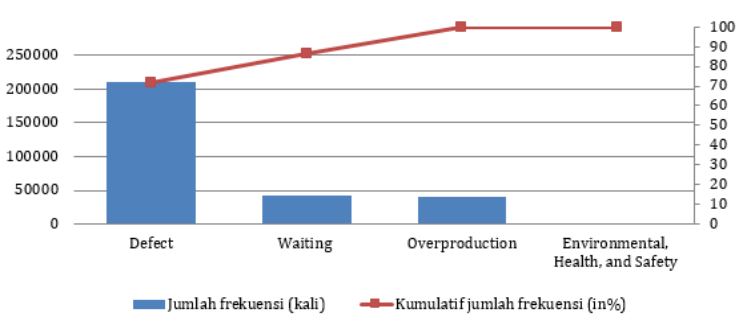

Gambar 3. Diagram pareto waste periode bulan Januari-Juni 2017

Langkah selanjutnya yaitu masuk pada tahap analyze. Pada tahap ini, dengan menggunakan metode root cause analysis (RCA) dilakukan identifikasi akar penyebab terjadinya waste defect untuk jenis cacat join gap tidak standar, karton rusak (gembos, krepek,dll), dan slotter melebihi standar. Hasil RCA menunjukkan penyebab cacat antara lain sebagai berikut:

1. Cacat join gap ada beberapa penyebab yaitu :

a. Penyebab pertama adalah sheet dari corrugating tidak beraturan, yang dikarenakan pisau pahat sudah aus. Akar permasalahannya adalah Kurangnya info dari shift sebelumnya tentang kondisi pisau pahat.

b. Penyebab kedua ialah proses folding kurang maksimal, yang dikarenakan belting mesin sering kendor penyebabnya adalah perawatan terhadap mesin masih kurang. Akar permasalahannya adalah kurangnya perawatan mesin secara berkala.

c. Penyebab ketiga adalah proses pembentukan gap yang tidak sempurna. Yang dikarenakan kinerja karyawan yang kurang maksimal penyebanya adalah kurangnya pengetahuan tentang perlakuan terhadap join gap. Akar permasalahannya adalah Hal ini terjadi karena jarang adanya pelatihan skill karyawan terhadap mesin.

2. Cacat pada karton rusak (gembos, krepek,dll) ada beberapa penyebab yaitu :

a. Penyebab pertama adalah proses pencampuran bahan kurang maksimal. Yang dikarenakan takaran bahan tidak sesuai standar. Akar permasalahannya adalah terjadi karena kecerobohan operator dalam pencampuran bahan.

b. Penyebab kedua adalah proses pengaturan suhu yang terlalu panas tidak sesuai oleh keadaan roll. Yang dikarenakan setting temperatur tidak sesuai dengan karakteristik bahan. Akar permasalahannya adalah tidak adanya info pergantian merek dan perubahan bahan.

c. Penyebab ketiga adalah penataan di area converting kurang maksimal, yang dikarenakan bahan yang diproduksi mesin corrugating overload adalah mesin di area converting sering rusak. Akar permasalahnnya adalah perawatan yang dipakai menggunakan sistem breakdown maintenance.

3. Cacat slotter melebihi standar ada beberapa penyebab yaitu :

a. Penyebab pertama adalah kinerja pisau pahat kurang maksimal. Yang dikarenakan pisau pahat sering aus. Akar permasalahannya kurangnya info dari shift sebelumnya tentang kondisi pisau pahat.

b. Penyebab kedua adalah sheet dari mesin corrugating tidak beraturan sehingga banyak yang melengkung. Akar permasalahannya adalah tidak adanya info dari pihak corrugating tentang keadaan sheet.

c. Penyebab ketiga adalah proses pengepresan tidak sesuai karakteristik sheet, yang dikarenakan skip pada feeder kurang maksimal penyebabnya adalah karet skip sudah aus. Akar permaslahannya adalah belum ada penjadwalan perawatan mesin secara berkala.

d. Penyebab keempat adalah kinerja karyawan yang kurang maksimal. Yang dikarenakan kurangnya penguasaan di mesin. Akar permasalahannya adalah hanya satu operator yang mengerti permasalahan yang terjadi di mesin.

Setelah diketahui akar penyebab masalah dari sub waste yang terjadi maka kemudian dilakukan diskusi lebih lanjut dengan atasan yang berwenang untuk menentukan nilai severity, occurance, dan detection untuk memperoleh nilai RPN (risk priority number). Dengan tujuan untuk mengetahui prioritas perbaikan yang dapat dilakukan. Pada tahapan ini digunakan metode failure mode effect analysis (FMEA) seperti yang ditunjukkan pada tabel 4 (Lampiran).

Berdasarkan metode FMEA yang dilakukan, diketahui nilai tertinggi berada pada penataan sheet di area converting kurang maksimal yang diakibatkan oleh mesin di area converting sering rusak dan perawatan mesin yang kurang maksimal yang dengan nilai RPN sebesar 128.

Tahap improve menggunakan konsep lean dan perhitungan preventive maintenance kemudian dilakukan berdasarkan hasil dari FMEA diatas. Rincian dari tahap improve sebagai berikut:

1. Menggunakan konsep lean

Berdasarkan RCA dan FMEA, nilai yang tertinggi pada penataan sheet di area converting yang kurang maksimal. Untuk perbaikannya kemudian dilakukan penataan ulang dengan konsep lean yang termasuk Necessary but Non-Value Adding ialah

a. Pastikan sheet dari mesin corrugating dalam keadaan baik 
b. Periksa sheet, bila ada sheet yang rusak maka sendirikan, tidak boleh dicampur dengan sheet yang baik.

c. Jika ditemukan sheet yang rusak disendirikan dan dimasukkan ke mesin balling press.

d. Lakukan pemeriksaan setiap 30 menit sekali.

e. Atur suhu sesuai standart perusahaan pada saat proses penggabungan kraft

f. Jika pisau pahat kurang tajam segeralah mengganti jika tidak maka akan mempengaruhi sheet. Akibatnya potongan sheet menjadi panjang pendek

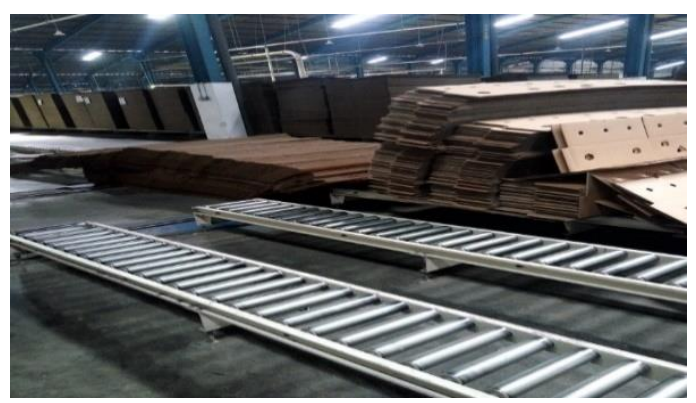

Gambar 4. Sebelum perbaikan di area converting

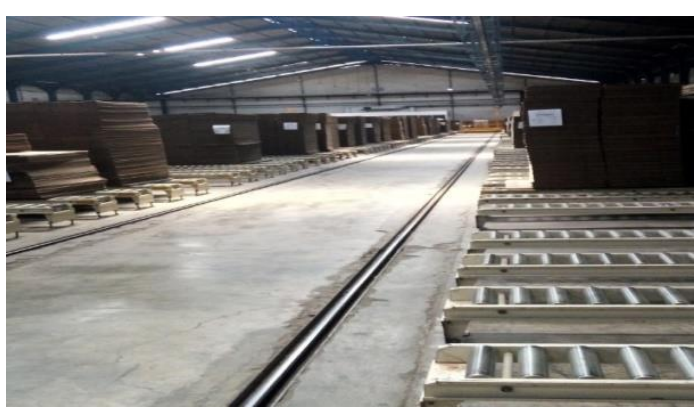

Gambar 5. Setelah perbaikan di area converting

Gambar 4 dan 5 menunjukkan kondisi area mesin converting sebelum dan sesudah perbaikan.

2. Menggunakan perhitungan preventive maintenance Perbaikan yang kedua untuk penyebab mesin converting yang sering rusak adalah dengan penyusunan jadwal perawatan mesin. Data perbaikan perawatan mesin ditunjukkan pada tabel 4 dibawah ini.

Tabel 4. Data perawatan mesin tahun 2017

\begin{tabular}{|l|c|c|c|l|c|}
\hline Bulan & $\begin{array}{l}\text { Total } \\
\text { pemeliharaan } \\
\text { preventif } \\
\text { (kali) }\end{array}$ & $\begin{array}{l}\text { Total } \\
\text { pemeliharaan } \\
\text { preventif } \\
\text { (jam) }\end{array}$ & $\begin{array}{l}\text { Total } \\
\text { pemeliharaan } \\
\text { korektif } \\
\text { (kali) }\end{array}$ & $\begin{array}{l}\text { Total } \\
\text { pemeliharaan } \\
\text { korektif } \\
\text { (jam) }\end{array}$ & $\begin{array}{l}\text { Jam kerja } \\
\text { efektif (jam) }\end{array}$ \\
\hline Januari & 4 & 4 & 8 & 6 & 666 \\
\hline Februari & 4 & 4 & 5 & 7,5 & 736,5 \\
\hline Maret & 4 & 4 & 6 & 9,5 & 710,5 \\
\hline April & 4 & 4 & 4 & 5 & 739 \\
\hline Mei & 4 & 4 & 3 & 3,5 & 716,5 \\
\hline Juni & 4 & 4 & 3 & 8 & 736 \\
\hline Total & 24 & 24 & 31 & 37,5 & 4304,5 \\
\hline
\end{tabular}

Untuk penyusunan jadwal kerusakan mesin dimulai dengan langkah-langkah sebagai berikut :

a. Menghitung laju kerusakan

Persamaan matematis yang digunakan untuk mencari laju kerusakan dengan menggunakan rumus :

$$
\begin{aligned}
\lambda=\frac{\mathrm{f}}{\mathrm{t}}= & \frac{\text { jumlah kerusakan yang terjadi }}{\text { waktu kerusakan keseluruhan }} \\
& =\frac{31}{4304.5}=0,007
\end{aligned}
$$

b. Menghitung Mean Maintenance Time (MCT)

Persamaan matematis yang digunakan untuk mencari mean maintenance time (MCT) dengan menggunakan rumus :

$$
\begin{aligned}
\text { MCT }= & \frac{\text { total waktu pemeliharaan }}{\text { banyaknya pemeliharaan korektif }} \\
& =\frac{37,3}{31}=1,2 \mathrm{jam}
\end{aligned}
$$

c. Menghitung rata rata pemeliharaan preventive Untuk menghitung rata - rata pemeliharaan preventive digunakan rumus :

$$
\begin{aligned}
\text { MPT } & =\frac{\text { total waktu pemeliharaan preventive }}{\text { banyaknya pemeliharaan preventive }} \\
& =\frac{24}{24}=1 \mathrm{jam}
\end{aligned}
$$

d. Menghitung Mean Time Between Failure (MTBF) Persamaan matematis yang digunakan adalah :

$$
\mathrm{MTBF}=\frac{1}{\lambda}=\frac{1}{0,007}=142,85 \mathrm{jam}
$$

e. Menghitung waktu rata- rata diantara pemeliharaan (MTBM)

Persamaan matematis yang digunakan adalah :

$$
\begin{gathered}
\text { MTBM } \frac{\text { total waktu efektif operasi mesin }}{\text { banyaknya pemeliharaan preventive dan korektif }} \\
=\frac{4304,5}{24+31}=76,86 \mathrm{jam}
\end{gathered}
$$

Jika melihat hasil MTBF maka mesin akan mengalami kerusakan rata-rata pada operasi selama 142,85 jam (5,9 hari). Sehingga mesin harus mendapat pemeliharaan sebelum waktu operasi selama 76,86 jam (3,2 hari). Perusahaan hendaknya membuat jadwal perawatan mesin secara berkala sehingga dapat mengurangi kerusakan mesin yang berlebih yang dapat menyebabkan kegagalan produksi. Berdasarkan data tersebut, maka berikut ini adalah usulan jadwal perawatan mesin converting (tabel 5) : 
Tabel 5. Jadwal perbaikan mesin

\begin{tabular}{|c|c|c|c|c|}
\hline No. & $\begin{array}{c}\text { Mesin } \\
\text { Converting }\end{array}$ & Hari & Perawatan & Keterangan \\
\hline 1 & Flexo 7 & Jumat & $\begin{array}{l}\text { Cleaning, } \\
\text { check } \\
\text { mesin, stel } \\
\text { belting, } \\
\text { stel feeder }\end{array}$ & $\begin{array}{l}\text { Semua } \\
\text { personil } \\
\text { fx.7, teknik } \\
\text { listrik dan } \\
\text { mekanik }\end{array}$ \\
\hline 2 & Flexo 8 & Minggu & $\begin{array}{l}\text { Cleaning, } \\
\text { check } \\
\text { mesin, } \\
\text { ganti pisau } \\
\text { pahat, stel } \\
\text { feeder }\end{array}$ & $\begin{array}{l}\text { Semua } \\
\text { personil } \\
\text { fx.8, teknik } \\
\text { listrik dan } \\
\text { mekanik }\end{array}$ \\
\hline 3 & Flexo 10 & Selasa & $\begin{array}{l}\text { Cleaning, } \\
\text { check } \\
\text { mesin }\end{array}$ & $\begin{array}{l}\text { Semua } \\
\text { personil } \\
\text { fx.10, } \\
\text { teknik } \\
\text { listrik dan } \\
\text { mekanik }\end{array}$ \\
\hline 4 & Flexo 11 & Minggu & $\begin{array}{l}\text { Cleaning, } \\
\text { check } \\
\text { mesin }\end{array}$ & $\begin{array}{l}\text { Semua } \\
\text { personil } \\
\text { fx.11, } \\
\text { teknik } \\
\text { listrik dan } \\
\text { mekanik }\end{array}$ \\
\hline
\end{tabular}

\section{PENUTUP}

Dari penelitian yang telah dilakukan dengan menerapkan konsep Lean DMAI, dapat ditarik kesimpulan yaitu rekomendasi Standar Operational Prosedures ( SOP) karena masih banyak penataan sheet yang kurang maksimal sehingga menyebabkan banyak cacat karton rusak masuk ke balling press. SOP yang diusulkan sebagai berikut:

1. Pastikan sheet dari mesin corrugating dalam keadaan baik.

2. Periksa sheet, bila ada sheet yang rusak maka sendirikan . tidak boleh dicampur dengan sheet yang baik.

3. Jika ditemukan sheet yang rusak disendirikan dan dimasukkan ke mesin balling press.
4. Lakukan pemeriksaan setiap 30 menit sekali.Atur suhu sesuai standart perusahaan pada saat proses penggabungan kraft.

5. Jika pisau pahat kurang tajam segeralah mengganti jika tidak maka akan mempengaruhi sheet .

6. Akibatnya potongan sheet menjadi panjang pendek.

7. Setiap karyawan yang masuk shift pagi dianjurkan melakukan penataan ulang sheet selama 3 jam sampai penataan benar- benar rapi

Berdasarkan hasil analisa pemeliharaan mesin juga dapat ditarik kesimpulan sebagai berikut:

1. Laju kerusakan mesin adalah 0,007 kerusakan/jam

2. Jadi mesin di converting akan mengalami kerusakan sebanyak 0,007 kerusakan /jam

3. Waktu rata- rata pemeliharaan korektif / Mean Corrective Time (MCT) adalah 1,2 jam

4. Sedangkan waktu untuk pemeliharaan preventive ialah 1 jam

5. Waktu rata-rata diantara kerusakan atau MTBF ialah 142,85 jam yang berarti mesin akan mengalami kerusakan setelah rata-rata beroperasi selama 142,85 jam atau 5,9 hari dan nilai ini juga menunjukkan umur operasi mesin.

Berdasarkan data diatas maka perusahaan hendaknya melakukan perbaikan kualitas pada proses produksi yang melibatkan seluruh karyawan baik bagian produksi maupun bagian maintenance untuk melaksanakan kegiatan sesuai SOP dan melakukan perawatan mesin secara berkala. Sedangkan untuk penelitian selanjutnya dapat menggunakan metode yang lain supaya dapat menghasilkan waktu perawatan mesin yang lebih detail.

\section{DAFTAR PUSTAKA}

Gaspers, V. (2008). The Excecutive Guide to Implementing. Gramedia Pustaka Utama.

Hines, Peter and Rich, N. (2006). The Seven Value Stream Mapping Tools. International Journal of Operation \& Production Management, 17(1), 46-04.

Pande, S. Peter, P. Neuman, Robert, R. Cavanagh, R. (2006). The Six Sigma Way. Yogyakarta: Penerbit Andi, Yogyakarta.

Womack, J. P., \& Jones, D. T. (1997). Lean thinking-banish waste and create wealth in your corporation. Journal of the Operational Research Society, 48(11), 1148. 
Lampiran ( Tabel 4. FMEA untuk waste yang paling berpengaruh)

\begin{tabular}{|c|c|c|c|c|c|c|c|c|c|c|}
\hline Itemwaste & Function proses & $\begin{array}{l}\text { Mode } \\
\text { keepagalan }\end{array}$ & $\begin{array}{l}\text { Alkibat } \\
\text { kequeganan }\end{array}$ & $\begin{array}{l}\text { S } \\
\text { e } \\
\text { v }\end{array}$ & $\begin{array}{l}\text { Penyebab } \\
\text { kepagatan } \\
\text { potensial }\end{array}$ & $\begin{array}{l}0 \\
\text { oc }\end{array}$ & $\begin{array}{l}\text { Kontrol } \\
\text { pencepahan saat } \\
\text { ini }\end{array}$ & $\begin{array}{l}\text { Deteksikontrol } \\
\text { santini }\end{array}$ & \begin{tabular}{l|}
$\mathbf{D}$ \\
$\mathbf{e}$ \\
$\mathbf{t}$
\end{tabular} & Rpn \\
\hline \multirow[t]{3}{*}{$\begin{array}{l}\text { Join pap tidak } \\
\text { standart }\end{array}$} & $\begin{array}{l}\text { Sheet dari corr corating } \\
\text { tidak beraturan (panjang } \\
\text { pendek) }\end{array}$ & $\begin{array}{l}\text { Karena pisau } \\
\text { pahat sudah } \\
\text { aus }\end{array}$ & $\begin{array}{l}\text { Cacat Join pap } \\
\text { karena pisau } \\
\text { yang aus } \\
\text { masuk balling } \\
\text { press }\end{array}$ & 8 & $\begin{array}{l}\text { Kurangaya info } \\
\text { dari sift } \\
\text { sebelumnya } \\
\text { tentang kondisi } \\
\text { pisau pahat }\end{array}$ & 5 & $\begin{array}{l}\text { Pencegahan } \\
\text { dilakukam } \\
\text { pengukuran setiap } \\
30 \text { menit sekali }\end{array}$ & $\begin{array}{l}\text { Deteksi cacat } \\
\text { mengeunakam } \\
\text { meteran }\end{array}$ & 2 & 80 \\
\hline & $\begin{array}{l}\text { Proses folding kurang } \\
\text { maksimal }\end{array}$ & $\begin{array}{l}\text { Dikaremakan } \\
\text { belting mesin } \\
\text { seringkendor }\end{array}$ & $\begin{array}{l}\text { Cacat join pap } \\
\text { karena belting } \\
\text { masuk } \\
\text { kategori preat } \\
\text { D }\end{array}$ & 7 & $\begin{array}{c}\text { Dikarenakan } \\
\text { kurangaya } \\
\text { perawatan mesin } \\
\text { secara berkala }\end{array}$ & 8 & $\begin{array}{l}\text { Perawatan mesin } \\
\text { dilakukan jika } \\
\text { belting sudah } \\
\text { rusak sija }\end{array}$ & $\begin{array}{l}\text { Deteksi cacat } \\
\text { mengeunakan } \\
\text { visual }\end{array}$ & 2 & 112 \\
\hline & $\begin{array}{l}\text { Proses pembentukan join } \\
\text { pap yang tidak sempurna }\end{array}$ & $\begin{array}{l}\text { Kinerja } \\
\text { operator } \\
\text { kurang } \\
\text { maksimal }\end{array}$ & $\begin{array}{l}\text { Cacat join pap } \\
\text { masuk Ereat C }\end{array}$ & 4 & $\begin{array}{l}\text { Dikaremakan jarang } \\
\text { adanya pelatihan } \\
\text { skill karyawan }\end{array}$ & 7 & $\begin{array}{l}\text { Himbauan dari } \\
\text { atasin untuk } \\
\text { penguasan di } \\
\text { mesin }\end{array}$ & $\begin{array}{l}\text { Deteksi cacat } \\
\text { mengerunakan } \\
\text { meteran }\end{array}$ & 2 & 56 \\
\hline \multirow[t]{3}{*}{ Karton rusak } & $\begin{array}{l}\text { Proses pencampuran } \\
\text { bahan masih kurang }\end{array}$ & $\begin{array}{l}\text { Dikaremakan } \\
\text { takaram baham } \\
\text { tidak sesuai }\end{array}$ & $\begin{array}{l}\text { Cacat karton } \\
\text { rusak masuk } \\
\text { kategori great }\end{array}$ & 7 & $\begin{array}{l}\text { Terjadi karena } \\
\text { kecerobohan }\end{array}$ & 8 & $\begin{array}{l}\text { Dilakukan } \\
\text { pengecekan selama } \\
15 \text { menit sekali }\end{array}$ & $\begin{array}{l}\text { Deteksi cacat } \\
\text { mengeunakan }\end{array}$ & 2 & 112 \\
\hline & $\begin{array}{l}\text { Proses pengaturam } \\
\text { suhu yang terlalu } \\
\text { panas }\end{array}$ & $\begin{array}{l}\text { Setting temperatur } \\
\text { tidak sesuai } \\
\text { dengan } \\
\text { karakteristik } \\
\text { bahan }\end{array}$ & $\begin{array}{l}\text { Cacat karton } \\
\text { rusck harus } \\
\text { dikerjakan } \\
\text { ulang }\end{array}$ & 6 & $\begin{array}{l}\text { Tidak adanya info } \\
\text { perpantian merek } \\
\text { dan perubahan } \\
\text { bahan }\end{array}$ & 8 & $\begin{array}{l}\text { Pengontrolan } \\
\text { dilakukan setiap } \\
\text { bahan masuk di } \\
\text { produksi }\end{array}$ & $\begin{array}{l}\text { Deteksi cacat } \\
\text { mengeunakam } \\
\text { visual }\end{array}$ & 2 & 96 \\
\hline & $\begin{array}{l}\text { Penataan sheet diarea } \\
\text { converting kurang } \\
\text { maksimal }\end{array}$ & $\begin{array}{l}\text { Bahan yang } \\
\text { diproduksi mesin } \\
\text { corr wotating } \\
\text { overload }\end{array}$ & $\begin{array}{l}\text { Cacat karton } \\
\text { rusak masuk } \\
\text { balling press }\end{array}$ & 8 & $\begin{array}{l}\text { Kuranenya } \\
\text { perawatan mesin } \\
\text { secara berkala }\end{array}$ & 8 & $\begin{array}{l}\text { Dilakukam } \\
\text { penataan ulang } \\
\text { dengan } \\
\text { menyendirikan } \\
\text { bahan yang rusak }\end{array}$ & $\begin{array}{l}\text { Deteksi cacat } \\
\text { menggunakan } \\
\text { visual }\end{array}$ & 2 & 128 \\
\hline \multirow[t]{3}{*}{$\begin{array}{l}\text { Slotter yang } \\
\text { melebihi } \\
\text { ukuran } \\
\text { standart }\end{array}$} & $\begin{array}{l}\text { Proses pahat yane } \\
\text { kuranemaksimal }\end{array}$ & $\begin{array}{l}\text { Piscau pahat sering } \\
\text { aus }\end{array}$ & $\begin{array}{l}\text { Cacat slotter } \\
\text { masuk } \\
\text { kategori preat } \\
\text { C }\end{array}$ & 4 & $\begin{array}{l}\text { Kuranpaya info } \\
\text { dari sift } \\
\text { sebelumnya } \\
\text { tentang kondisi } \\
\text { pisau pahat }\end{array}$ & 7 & $\begin{array}{l}\text { Di buatkan check } \\
\text { list kondisi mesin }\end{array}$ & $\begin{array}{c}\text { Deteksi cacat } \\
\text { mengeunakan } \\
\text { meteran }\end{array}$ & 2 & 56 \\
\hline & $\begin{array}{l}\text { Proses penantaan } \\
\text { sheet tidak beraturan }\end{array}$ & $\begin{array}{l}\text { Tidak a danya info } \\
\text { dari pihak } \\
\text { corr wating } \\
\text { tentang kondisi } \\
\text { seet }\end{array}$ & $\begin{array}{l}\text { Cacat slotter } \\
\text { masuk } \\
\text { kategori great } \\
\text { B }\end{array}$ & 3 & $\begin{array}{l}\text { Tidak adanya info } \\
\text { dari pihak } \\
\text { corr cifating } \\
\text { tentang keadaan } \\
\text { sheet }\end{array}$ & 8 & $\begin{array}{l}\text { Pencepghan } \\
\text { dilakuakan dengan } \\
\text { penataan ulang } \\
\text { sheet }\end{array}$ & $\begin{array}{l}\text { Deteksi cacat } \\
\text { mengeunakan } \\
\text { visual }\end{array}$ & 2 & 48 \\
\hline & $\begin{array}{l}\text { Proses pengepressm } \\
\text { tidak sesuai }\end{array}$ & $\begin{array}{l}\text { Karema kinerja } \\
\text { skip feeder kurang } \\
\text { maksimal }\end{array}$ & $\begin{array}{l}\text { Cacat slotter } \\
\text { masuk Ereat D }\end{array}$ & 7 & $\begin{array}{l}\text { Belumada } \\
\text { penjadwalan } \\
\text { perawatan mesin }\end{array}$ & 8 & $\begin{array}{l}\text { Melakukam } \\
\text { perawatan mesin } \\
\text { jika rusask saja }\end{array}$ & $\begin{array}{l}\text { Deteksi cacat } \\
\text { mengernakan } \\
\text { visual }\end{array}$ & 2 & 112 \\
\hline & $\begin{array}{l}\text { Kinerja karyawan } \\
\text { kurangmaksimal }\end{array}$ & $\begin{array}{l}\text { Kurangnya } \\
\text { penguassan di } \\
\text { mesin }\end{array}$ & $\begin{array}{l}\text { Cacat slotter } \\
\text { masuk Ereat B }\end{array}$ & 3 & $\begin{array}{l}\text { Hanya satu oprator } \\
\text { yang mengerti } \\
\text { permaslahan } \\
\text { mesin }\end{array}$ & 7 & $\begin{array}{l}\text { Himbauan dari } \\
\text { atasan untuk } \\
\text { penguassan di } \\
\text { mesin }\end{array}$ & $\begin{array}{c}\text { Deteksi cacat } \\
\text { mengeunakam } \\
\text { meteran }\end{array}$ & 2 & 42 \\
\hline
\end{tabular}


A.A Santoso, dkk /JISO, Vol. 1, No.1, Desember 2018, 39-46

Halaman ini sengaja dikosongkan 